\title{
Interaction between Lactococcus lactis and Lactococcus raffinolactis during growth in milk: Development of a new starter culture
}

\author{
H. Kimoto-Nira, ${ }^{\star 1}{ }^{1}$ R. Aoki, ${ }^{*}$ K. Mizumachi, ${ }^{*}$ K. Sasaki, ${ }^{*}$ H. Naito, $†$ T. Sawada, $†$ and C. Suzuki ${ }^{\star}$ \\ *NARO Institute of Livestock and Grassland Science, Ikenodai 2, Tsukuba, Ibaraki 305-0901, Japan \\ †Amita Corporation, 28, 3 Bancho, Chiyoda, Tokyo 102-0075, Japan
}

\begin{abstract}
Many milk fermentations use mixed cultures of lactic acid bacteria. To select a new mixed starter culture, 100 acid-producing bacterial strains were isolated from raw cow milk. Of these, 13 strains identified as belonging to the genera Lactococcus, Lactobacillus, Leuconostoc, or Weissella (based on phenotypic and genotypic tests) were assessed for a symbiotic effect between pairs of isolated strains during growth in milk. Among the strains tested, a mixed culture of Lactococcus lactis ssp. lactis strain 54 and Lactococcus raffinolactis strain 37 stimulated greater acid production during fermentation than occurred with pure fermentation. This stimulatory effect was not observed in milk supplemented with yeast extract or glucose or in constituted medium. Addition of a cell-free filtrate from milk fermented by strain 54 increased acid production by strain 37; however, the converse effect was not observed. The increased acid production by this mixed culture was, therefore, due to stimulation of strain 37 by metabolic products of strain 54 , suggesting that the interaction between strains 54 and 37 is commensal. Analysis with a taste-sensing system indicated that fermented milk containing the mixed culture was more acidic, had more anionic bitterness, had greater aftertastes of anionic bitterness and astringency, and was less salty and umami than milk containing the individual cultures. This study identifies a new commensal relationship between 2 lactococcal strains that are commonly used for making dairy products.
\end{abstract}

Key words: lactic acid bacteria, starter culture, symbiosis

\section{INTRODUCTION}

Lactic acid bacteria are widely used as starter bacteria in the manufacture of fermented dairy products, such as cheese and yogurt. Recently, in many countries,

Received August 11, 2011.

Accepted November 28, 2011.

${ }^{1}$ Corresponding author: anne@affrc.go.jp consumers have begun to favor more diverse organoleptic properties and food textures (Chee et al., 2005; Isleten and Karagul-Yuceer, 2006; Thompson et al., 2007). Accordingly, there is great interest in the development of new starter cultures for fermented products. These fermented products are typically produced by using mixed cultures of lactic acid bacteria rather than pure cultures, because pure strains often grow slowly in medium and mixed cultures can improve the flavor (Kothari et al., 1971; Frengova et al., 2000). In mixed starter cultures, it is important that the growth of each lactic acid bacterium is not inhibited by mixing and that the bacteria stimulate each other's growth and acid production. For example, yogurt is made from milk fermented by a mixed culture of Streptococcus thermophilus and Lactobacillus delbrueckii ssp. bulgaricus (Sieuwerts et al., 2008). Streptococcus thermophilus consumes purine (precursors) in milk provided by $L$. delbrueckii ssp. bulgaricus and its growth is thus supported (Herve-Jimenez et al., 2009). Streptococcus thermophilus provides L. delbrueckii ssp. bulgaricus with formic acid (Derzelle et al., 2005), folic acid (Crittenden et al., 2003), and carbon dioxide (Driessen et al., 1982). Kefir is a fermented milk beverage that originated in Eastern Europe. The starter is kefir grain, a complex starter culture made up of various kinds of lactic acid bacteria (lactobacilli, streptococci, and lactococci) that are microbial symbionts (Margulis, 1996; Simova et al., 2002). For example, Simova et al. (2006) reported that Lactobacillus helveticus MP12 strain produces amino acids, which intensify cell growth activity in lactobacilli and cocci in kefir. An interaction between Leuconostoc lactis CNRZ 1091 and Lactococcus lactis ssp. cremoris AM2 has also been reported (Boquien et al., 1988). In this case, the mixed culture improved the maximum growth rate of $L$. lactis by $50 \%$, whereas that of $L$. lactis ssp. cremoris was unaffected. Therefore, the interaction between these strains is commensal: one strain produces or releases compounds that promote the growth of the other (Meers, 1973).

With the aim of developing new industrial starter cultures, we first isolated from raw cow milk lactic acid bacterial strains with useful properties and then identi- 
fied mixed cultures of the isolated strains that demonstrated symbiotic growth. The characteristics of the interactions between these lactic acid bacterial strains during growth in milk were also investigated.

\section{MATERIALS AND METHODS}

\section{Raw Milk Sampling}

The 7 Jersey dairy cows (cows A, B, C, D, E, F, and G) used in this study were housed on pasture at a farm in Kyotango, Japan. Bramley et al. (1984) reported differences in bacterial flora in raw milk from cows with mastitis and that from healthy cows. The cows used in this study had no subclinical or clinical mastitis. A raw milk sample (about $20 \mathrm{~mL}$ ) from 1 or 2 mammary glands of each cow was collected following teat disinfection, whereby a towel moistened with cationic surfactant was used to wipe the teat and the sample was collected in a sterile tube on December 14, 2009. The collected samples were kept at $4^{\circ} \mathrm{C}$, and the analysis was performed within $24 \mathrm{~h}$ of sampling.

\section{Isolation of Lactic Acid Bacteria for Starter Cultures}

Each raw milk sample was inoculated on 5 types of agar plates, each containing one of the following: (1) deMan, Rogosa, and Sharpe (MRS) broth (Becton Dickinson and Co., Sparks, MD) to which 1.6\% agar and $0.8 \% \mathrm{CaCO}_{3}$ were added; (2) $10 \%$ skim milk (Snow Brand Co., Sapporo, Japan) with $0.005 \%$ bromocresol purple and $1.6 \%$ agar; (3) $10 \%$ skim milk with $0.005 \%$ bromocresol purple, $0.3 \%$ yeast extract (Wako Chemical, Osaka, Japan), 0.5\% glucose, and 1.6\% agar; (4) acetate agar (Rogosa et al., 1951); and (5) AC agar plates (Nissui Seiyaku, Tokyo, Japan). Milk media were sterilized by autoclaving at $121^{\circ} \mathrm{C}$ for $10 \mathrm{~min}$. Other media were sterilized by autoclaving at $121^{\circ} \mathrm{C}$ for 15 min.

Acid-producing bacteria were detected on MRS broth with $\mathrm{CaCO}_{3}$. Presumptive lactobacilli were detected on acetate agar medium (Rogosa et al., 1951), and enterococci were detected on AC agar plates. The plates were incubated for $2 \mathrm{~d}$ at $30^{\circ} \mathrm{C}$ for MRS agar and milk agar or $37^{\circ} \mathrm{C}$ for acetate agar and $\mathrm{AC}$ agar. Colonies that dissolved in $\mathrm{CaCO}_{3}$ and formed clear zones around their colonies in MRS agar plates were isolated at random. Yellow colonies on milk agar and all colonies on acetate agar and AC agar were isolated. The broths inoculated with each colony were cultivated at $30^{\circ} \mathrm{C}$ or $37^{\circ} \mathrm{C}$ and tested for catalase activity. Briefly, the cultures were centrifuged and $15 \%$ (vol/vol) $\mathrm{H}_{2} \mathrm{O}_{2}$ was added to the pellets. Gas production was indicative of catalase- positive bacterial strains. The pure, gram-positive, and catalase-negative isolated strains were stored at $-80^{\circ} \mathrm{C}$ in MRS broth supplemented with $15 \%$ glycerol.

Working cultures were revitalized by one transfer in MRS or tryptone-yeast extract-glucose (TYG) broth at $30^{\circ} \mathrm{C}$ for mesophilic lactic acid bacteria and $37^{\circ} \mathrm{C}$ for thermophilic lactic acid bacteria, respectively. The TYG broth consisted of 0.5\% tryptone (Becton Dickinson and Co.), $0.5 \%$ yeast extract, and $1.0 \%$ glucose supplemented with $1 \%$ sodium succinate and $1 \%$ sodium chloride and was adjusted to $\mathrm{pH} 6.86$.

To develop new starter cultures, we selected the isolated strains by growth on 3 kinds of liquid milk culture (i.e., $10 \%$ skim milk alone, $10 \%$ skim milk with $0.3 \%$ yeast extract, and $10 \%$ skim milk with $0.3 \%$ yeast extract plus $0.5 \%$ glucose) at $30^{\circ} \mathrm{C}$ for 1 to $2 \mathrm{~d}$. Strains with the ability to coagulate milk were selected and identified.

\section{Identification of the Strains}

To identify lactic acid bacterial strains, the $16 \mathrm{~S}$ rRNA gene was amplified and sequenced by using the primer pair 27F/1406R (Suzuki and Giovannoni, 1996). In addition, the housekeeping genes rpo $A$ (encoding the DNA-dependent RNA polymerase $\alpha$-subunit) and pheS (encoding the phenylalanyl-tRNA synthase $\alpha$-subunit) were amplified and sequenced by using the primer pairs rpoA-21-F/rpoA-22-R (Naser et al., 2007) and pheS21-F/pheS-21-R (Naser et al., 2005), respectively. The PCR conditions used for rpoA and pheS were those described by Naser et al. (2005), except for an annealing temperature of $54^{\circ} \mathrm{C}$. The DNA sequences were analyzed by the 3730 DNA Analyzer (Applied Biosystems, Foster City, CA). The BLAST algorithm was used to determine the most closely related sequences in the NCBI nucleotide sequence database (http://www.ncbi. nlm.nih.gov/BLAST).

A PCR-based method was also used for specific Lactococcus lactis ssp. lactis identification (Nomura et al., 2002). Briefly, bacterial cultures $\left(10^{7} \mathrm{cfu}\right)$ were used as templates for PCR analyses. Primers were designed from the glutamate decarboxylase gene sequence of $L$. lactis ssp. lactis bv. diacetylactis 01-7. A 600-bp PCR fragment would be amplified from the strain belonging to L. lactis ssp. lactis. Lactococcus strains other than L. lactis were identified by analysis of PCR products (approximately $860 \mathrm{bp}$ ) amplified by using primers PiplraR and 1RL (Pu et al., 2002).

Several physiological tests of the strains were carried out: microscopic observation of bacterial shape; growth at $40^{\circ} \mathrm{C}$ and $45^{\circ} \mathrm{C}$ in MRS broth for $1 \mathrm{~d}$; and growth in MRS broth with $4 \%$ and $6.5 \% \mathrm{NaCl}$ for 2 d. Sugar 
fermentation and hydrolysis of arginine were assessed by using an API 20 STREP kit (BioMerieux, Marcy I'Etoile, France) for cocci strains.

Strains belonging to the genera Lactobacillus, Leuconostoc, Lactococcus, and Weissella were selected as candidates for starter bacteria in this study because Lactobacillus, Leuconostoc, and Lactococcus are generally recognized as safe (Salminen et al., 1998; Ogier et al., 2008), and some strains of Weissella have been used as starters for fermented products (Galle et al., 2010).

\section{Screening Cultures for Associative Growth in Mixed Culture}

To screen strains for associative growth in mixed cultivation, a tube containing $4 \mathrm{~mL}$ of $10 \%$ skim milk was inoculated with $1 \%$ of 2 different strains in pure and mixed culture: the size of the inoculum in the mixed culture was therefore at the $0.5 \%$ level for each strain. The cultures were incubated at $30^{\circ} \mathrm{C}$ or $37^{\circ} \mathrm{C}$ for $24 \mathrm{~h}$, at which time the $\mathrm{pH}$ value of the culture was determined. Any interaction occurring in mixed cultures is reflected by acid production (Kothari et al., 1971; Hugenholtz et al., 1987). The acidification of growth medium in batch culture is a good reflection of bacterial growth, which is why $\mathrm{pH}$ measurement is sometimes used to track growth (Cogan, 1978).

To test selected strains 37 and 54 for associative growth, pure and mixed cultivation were conducted in constituted media: $4 \mathrm{~mL}$ of TYG, tryptone-yeast extract-lactose (TYL), and TYL with $0.2 \%$ ammonium citrate. The TYL broth included $0.5 \%$ lactose instead of glucose, and these broths were adjusted to $\mathrm{pH} 6.86$.

\section{Viable Count of the Selected Strains}

To distinguish and enumerate the selected strains (37 and 54) from the fermented milk in the pure and mixed cultures, we diluted the fermented milk samples in sterile $0.85 \% \mathrm{NaCl}$, plated them on MRS agar medium, and incubated them at $30^{\circ} \mathrm{C}$. Because strain 37 grew slowly in MRS agar but strain 54 did not, the small colonies on the MRS medium were strain 37 , and the large colonies were strain 54 .

In addition, we examined whether this associative growth was stable by inoculating the 2 cultures 3 times in milk and determining the viable count for each.

\section{Preparation of a Cell-Free Culture Capable of Stimulating Acid Production During Associative Growth}

Individual cell-free filtrates of milk cultures fermented by the selected strains were prepared by the method of
Kothari et al. (1971). Briefly, $50 \mathrm{~mL}$ of milk was inoculated with a fresh overnight culture at the $1 \%$ level and incubated at $30^{\circ} \mathrm{C}$ for $24 \mathrm{~h}$. The cultures were kept at 45 to $50^{\circ} \mathrm{C}$ for $30 \mathrm{~min}$ in a water bath. The whey was then filtered and adjusted to $\mathrm{pH} 7.0$ with $\mathrm{NaOH}$. Control whey was prepared by adding $2.5 \mathrm{~mL}$ of $10 \%$ lactic acid to $50 \mathrm{~mL}$ of fresh sterilized skim milk. The culture filtrates were added to the comparison cultures. The mixed cultures were incubated at $30^{\circ} \mathrm{C}$ for $24 \mathrm{~h}$ and $\mathrm{pH}$ value was then determined.

\section{Mechanical Taste Sensing of Fermented Milk}

Fifty milliliters of skim milk (10\%) was inoculated with a fresh overnight culture at the $1 \%$ level and incubated at $30^{\circ} \mathrm{C}$ for $24 \mathrm{~h}$. The cultures were diluted 5 -fold with water and centrifuged at $2,800 \times g$ at $4^{\circ} \mathrm{C}$ for $20 \mathrm{~min}$. The supernatant was then analyzed by means of the taste-sensing system SA402 (INSENT, Tokyo, Japan). The system comprises 5 taste sensors derived from polymer membranes that fix different lipids. The sensors CT0, CA0, AAE, C00, and AE1 were designated to respond to the individual initial tastes of saltiness, acidity, umami, anionic bitterness, and astringency, respectively (Toko, 1996, 1998), and anionic bitterness, astringency, and umami were measured as aftertastes (Chikuni et al., 2010). Initial taste is the taste a person senses when food, drink, or both are in the mouth, whereas aftertaste is the taste a person senses after swallowing food, drink, or both. The measurement procedure was described by Anjiki et al. (2011). Briefly, zero-adjusted probes were applied to a sample solution, and the sample output was collected as initial tastes. Next, a sensor buffer solution $(30 \mathrm{mM} \mathrm{KCl}$ plus 0.3 $\mathrm{m} M \mathrm{~L}-(+)$-tartaric acid solution) was measured before the probe was washed. This output indicated the membrane potential caused by adsorption, which represents an aftertaste. Probes were then washed with the buffer solution and zero-adjusted for measurement of the next sample. All measurement procedures were carried out at room temperature. The sensor signals for each sample are reported as the difference from the sensor buffer solution and converted to values corresponding to the individual tastes with the following formulas: converted value of $\mathrm{CT} 0$ output $(\mathrm{cvCT} 0)=-0.25 \times \mathrm{CT} 0$ signal; converted value of $\mathrm{CA} 0$ output $(\mathrm{cvCA} 0)=0.33$ $\times$ CA0 signal; converted value of AAE output (cvAAE) $=-0.16 \times \mathrm{AAE}$ signal; converted value of $\mathrm{C} 00$ output $(\mathrm{cvC} 00)=-0.14 \times \mathrm{C} 00$ signal $+0.08 \times \mathrm{CT} 0$ signal; and converted value of AE1 output $(\operatorname{cvAE} 1)=-0.16$ $\times$ AE1 signal $+0.16 \times$ CT0 signal. A converted value of 1 corresponds to a $20 \%$ difference from the buffer solution in sensory system SA402 (Sasaki et al., 2005; Chikuni et al., 2010). 


\section{Statistical Analysis}

The $\mathrm{pH}$ values in media, bacterial counts (log cfu/ $\mathrm{mL}$ ), and relative intensity of taste in fermented milk were expressed as least squares means \pm standard errors of 2 or 3 replicates analyzed by the generalized linear model (GLM) procedure of the SAS system (version 9.1, SAS Institute Inc., Cary, NC). Differences between least squares means were analyzed by the Tukey-Kramer test using the PDIFF option of the GLM procedure of the SAS system. Statistical significance was defined as $P<0.05$.

\section{RESULTS}

\section{Isolation and Identification of Lactic Acid Bacteria}

One hundred acid-producing bacterial strains were isolated from 6 of the 7 raw milk samples. The milk sample from cow $\mathrm{G}$ did not produce any colonies on the agar plates used. Bacterial cell counts from samples on MRS agar, milk agar, or acetate agar ranged from 10 to $10^{2} \mathrm{cfu} / \mathrm{mL}$. No colonies were found on AC agar plates. Of the 100 isolated strains, 43 strains grew in 10\% skim milk with yeast extract and glucose, the medium used to assess milk clotting. These strains were subjected to identification tests as candidates for dairy starters. No strains isolated from cow F's milk could be grown in milk, and thus they were not identified.

Among the 43 strains that grew in milk, 11 were Enterococcus spp., 1 was a Lactobacillus sp., 14 were Lactococcus spp., 1 was a Leuconostoc sp., 5 were Streptococcus spp., 5 were Weissella spp., and 6 were unidentified strains. From 2 to 5 species were detected in each cow's milk. Milk from cow A had 2 strains of Enterococcus, 1 strain of Lactobacillus, 5 strains of Lactococcus, 4 strains of Streptococcus, and 1 strain of Weissella. Milk from cow B had 1 strain of Enterococcus and 2 strains of Lactococcus. Milk from cow C had 5 strains of Enterococcus, 6 strains of Lactococcus, 1 strain of Streptococcus, 3 strains of Weissella, and 1 unidentified strain. Milk from cow D had 3 strains of Enterococcus, 1 strain of Lactococcus, and 2 unidentified strains. Milk from cow E had 1 strain of Leuconostoc, 1 strain of Weissella, and 3 unidentified strains. The 14 isolated lactococcal strains included 7 strains of L. lactis ssp. lactis and 7 strains of L. raffinolactis (data not shown).

Seven strains of L. lactis ssp. lactis (strains 8, 16, 21, 22, 36, 54, and 95), 3 strains of L. raffinolactis (strains 9, 37, and 93), 1 strain of Lactobacillus plantarum (strain 19), 1 strain of Leuconostoc mesenteroides (strain 89), and 1 strain of Weissella paramesenteroides (strain 51) were screened as associative mixed starters. Their physiological and biochemical characteristics and ability to clot milk for use as dairy starter are shown in Table 1. All strains except 19 and 51 were grampositive, catalase negative, and cocci in pairs or short chains. Strains 19 and 51 were gram-positive, catalase negative, and rod-shaped in short chains. Among the 13 strains shown in Table 1, L. lactis ssp. lactis strains 8 and 54 coagulated milk within $1 \mathrm{~d}$ with glucose and within $2 \mathrm{~d}$ without it (Table 1 ). In the organoleptic trial, fermented milk with strain 54 had more yogurt flavor than that with strain 8 . Thus, strain 54 was selected as a candidate dairy starter bacterium.

\section{Acid Production by Pure and Mixed Cultures of Isolated Lactic Acid Bacteria in Milk}

The acid production by pairs of cultures (strain 54 with other strains) grown in milk is shown in Table 2. In cultivation at $30^{\circ} \mathrm{C}$ and $37^{\circ} \mathrm{C}$, a significant decrease of the $\mathrm{pH}$ value was not observed in any mixed culture. The $\mathrm{pH}$ value of the milk was lowest for pair 54 and 37, although the decrease was not significant. Thus, strain 37 was selected for mixed starter with strain 54 .

\section{Acid Production by Pure and Mixed Cultures of Isolated Lactic Acid Bacteria in Different Media}

The $\mathrm{pH}$ values of pure and mixed cultures of strains 37 and 54 on different media are shown in Table 3 . The $\mathrm{pH}$ value in milk was significantly lowered by mixed cultivation of strains 37 and 54 compared with that of each pure culture. In pure culture, the $\mathrm{pH}$ value of strain 37 or 54 in milk with yeast extract or glucose was significantly lower than that without it, whereas the $\mathrm{pH}$ value was not lowered by mixed cultures. On the other hand, the strains could grow in TYG, TYL with citrate, and TYL broth in pure culture. The $\mathrm{pH}$ values were not lowered by mixed cultures in TYG, TYL with citrate, or TYL broth.

\section{Potency of Stimulatory Materials}

The effect of adding a cell-free filtrate from strain 54 on acid production in a strain 37 culture is shown in Table 4 . Skim milk fermented by strain 54 was slightly clotting, whereas that fermented by strain 37 was not, and thus, a cell-free filtrate from strain 37 was not prepared. The control whey was prepared by adding lactic acid to skim milk. Addition of the strain 54 filtrate significantly increased acid production in the strain 37 culture relative to the control samples, to which the control whey was added. No significant progressive increase in acid production was observed with the addition of water to the strain 37 culture. 
Table 1. Some characteristics of candidates starter strains isolated from raw milk ${ }^{1}$

\begin{tabular}{|c|c|c|c|c|c|c|c|c|c|c|c|c|c|}
\hline \multirow[b]{2}{*}{ Species and strain no. } & \multicolumn{2}{|c|}{ Growth at } & \multicolumn{2}{|c|}{$\begin{array}{l}\text { Growth in the } \\
\text { presence of }\end{array}$} & \multicolumn{3}{|c|}{ Fermentation of } & \multirow[b]{2}{*}{$\begin{array}{l}\text { Hydrolysis } \\
\text { of arginine }\end{array}$} & \multicolumn{4}{|c|}{ Milk clotting $^{2}$} & \multirow[b]{2}{*}{$\begin{array}{l}\text { Source of } \\
\text { raw milk }\end{array}$} \\
\hline & $40^{\circ} \mathrm{C}$ & $45^{\circ} \mathrm{C}$ & $4 \% \mathrm{NaCl}$ & $\begin{array}{l}6.5 \% \\
\mathrm{NaCl}\end{array}$ & Lactose & Mannitol & Raffinose & & Milk & $\begin{array}{l}\text { Milk } \\
\text { plus Y }\end{array}$ & $\begin{array}{l}\text { Milk } \\
\text { plus G }\end{array}$ & $\begin{array}{c}\text { Milk } \\
\text { plus YG }\end{array}$ & \\
\hline \multicolumn{14}{|l|}{ Lactococcus lactis ssp. lactis } \\
\hline 8 & + & - & + & - & + & - & - & + & + & ++ & ++ & ++ & Cow A \\
\hline 16 & + & - & + & - & + & + & + & + & - & ++ & - & ++ & Cow A \\
\hline 21 & + & - & + & - & + & - & - & + & - & ++ & - & ++ & Cow B \\
\hline 22 & + & - & + & - & + & + & - & + & - & ++ & - & ++ & Cow B \\
\hline 36 & + & - & + & - & - & + & + & + & - & ++ & - & ++ & Cow $\mathrm{C}$ \\
\hline 54 & + & - & + & - & + & - & - & + & + & ++ & ++ & ++ & Cow $\mathrm{C}$ \\
\hline 95 & + & - & + & - & + & + & + & + & - & ++ & - & ++ & Cow $\mathrm{C}$ \\
\hline \multicolumn{14}{|l|}{ Leuconostoc mesenteroides } \\
\hline \multirow{2}{*}{\multicolumn{14}{|c|}{ Lactococcus raffinolactis }} \\
\hline & & & & & & & & & & & & & \\
\hline 9 & - & - & - & - & + & + & + & - & - & ++ & - & ++ & Cow A \\
\hline 37 & - & - & - & - & + & + & + & - & - & ++ & - & ++ & Cow C \\
\hline 93 & - & - & - & - & + & + & + & - & - & ++ & - & ++ & Cow A \\
\hline \multirow{4}{*}{$\begin{array}{l}\text { Lactobacillus plantarum } \\
19 \\
\text { Weissella paramesenteroides } \\
51\end{array}$} & & & & & & & & & & & & & \\
\hline & + & - & + & - & $\mathrm{ND}^{3}$ & ND & ND & ND & - & ++ & - & ++ & Cow A \\
\hline & & & & & & & & & & & & & \\
\hline & + & - & + & - & ND & ND & ND & ND & - & ++ & - & ++ & Cow $\mathrm{C}$ \\
\hline
\end{tabular}

${ }^{1}$ Lactococcus strains were grown at $30^{\circ} \mathrm{C} ;$ Lactobacillus and Weissella strains were grown at $37^{\circ} \mathrm{C}$.

${ }^{2}$ Milk $=10 \%$ skim milk; milk plus $\mathrm{Y}=10 \%$ skim milk plus $0.3 \%$ yeast extract; milk plus $\mathrm{G}=10 \%$ skim milk plus $0.5 \%$ glucose; milk plus YG $=10 \%$ skim milk plus $0.3 \%$ yeast extract and $0.5 \%$ glucose. Milk clotting: $++=$ coagulated within $1 \mathrm{~d} ;+=$ coagulated within $2 \mathrm{~d} ;-=$ did not coagulate

${ }^{3} \mathrm{ND}=$ not done 
Table 2. $\mathrm{pH}_{\text {values }}{ }^{1}$ of milk for pure or mixed cultures of isolated strains ${ }^{2}$ and Lactococcus lactis ssp. lactis strain 54

\begin{tabular}{|c|c|c|c|c|}
\hline \multirow[b]{2}{*}{ Species and strain no. } & \multicolumn{2}{|c|}{ Cultivation at $30^{\circ} \mathrm{C}$} & \multicolumn{2}{|c|}{ Cultivation at $37^{\circ} \mathrm{C}$} \\
\hline & Pure & Mixed & Pure & Mixed \\
\hline \multicolumn{5}{|l|}{ Lactococcus lactis ssp. lactis } \\
\hline 54 & $5.03 \pm 0.03^{\mathrm{e}}$ & $\mathrm{ND}^{3}$ & $5.08 \pm 0.02^{\mathrm{bc}}$ & ND \\
\hline 8 & $5.16 \pm 0.03^{\mathrm{de}}$ & $5.11 \pm 0.03^{\mathrm{de}}$ & & \\
\hline 16 & $5.18 \pm 0.03^{\mathrm{de}}$ & $5.10 \pm 0.03^{\text {de }}$ & & \\
\hline 21 & $5.21 \pm 0.03^{\mathrm{de}}$ & $5.07 \pm 0.03^{\mathrm{de}}$ & & \\
\hline 22 & $5.29 \pm 0.03^{\mathrm{d}}$ & $4.99 \pm 0.03^{\mathrm{e}}$ & & \\
\hline 36 & $5.93 \pm 0.03^{\mathrm{a}}$ & $5.06 \pm 0.03^{\mathrm{e}}$ & & \\
\hline \multirow{2}{*}{\multicolumn{5}{|c|}{ Leuconostoc mesenteroides }} \\
\hline & & & & \\
\hline 89 & $6.11 \pm 0.03^{\mathrm{a}}$ & $4.94 \pm 0.03^{\mathrm{e}}$ & & \\
\hline \multicolumn{5}{|l|}{ Lactococcus raffinolactis } \\
\hline 9 & $5.59 \pm 0.03^{\mathrm{bc}}$ & $5.05 \pm 0.03^{\mathrm{e}}$ & & \\
\hline 37 & $5.48 \pm 0.03^{\mathrm{c}}$ & $4.88 \pm 0.03^{\mathrm{e}}$ & & \\
\hline 93 & $5.67 \pm 0.03^{\mathrm{b}}$ & $5.07 \pm 0.03^{\mathrm{de}}$ & & \\
\hline \multicolumn{5}{|l|}{ Lactobacillus plantarum } \\
\hline 19 & $5.43 \pm 0.03^{\mathrm{cd}}$ & $5.07 \pm 0.03^{\mathrm{e}}$ & $5.32 \pm 0.02^{\mathrm{a}}$ & $4.98 \pm 0.02^{c}$ \\
\hline $\begin{array}{l}\text { Weissella paramesenteroides } \\
51\end{array}$ & $5.52 \pm 0.03^{\mathrm{bc}}$ & $5.25 \pm 0.03^{\mathrm{d}}$ & $5.28 \pm 0.02^{\mathrm{a}}$ & $5.10 \pm 0.02^{\mathrm{b}}$ \\
\hline
\end{tabular}

${ }^{\mathrm{a} e} \mathrm{Mean} \mathrm{pH}$ values within the same cultivation temperature with different superscript letters are significantly different $(P<0.05)$.

${ }^{1}$ Results are means \pm SE from duplicate samples.

${ }^{2}$ Lactococcus lactis ssp. lactis strain 54 was cultivated with other strains in $10 \%$ skim milk at $30^{\circ}$ or $37^{\circ} \mathrm{C}$ for 24 h. Lactococcus strains were grown at $30^{\circ} \mathrm{C}$. Lactobacillus and Weissella strains were grown at $30^{\circ}$ and $37^{\circ} \mathrm{C}$. ${ }^{3} \mathrm{ND}=$ not done.

\section{Viable Cell Counts in Pure and Mixed Cultures}

Changes in viable cell count and milk $\mathrm{pH}$ value during cultivation of pure and mixed cultures of strains 37 and 54 are shown in Figures 1a and 1b, respectively. At cultivation time $0 \mathrm{~h}$ (before starting fermentation), the viable cell count of strain 37 in mixed culture $(6.47 \pm$ $0.09 \log \mathrm{cfu} / \mathrm{mL})$ was significantly lower $(P=0.034)$ than that in pure culture $(7.09 \pm 0.12 \log \mathrm{cfu} / \mathrm{mL})$. From 0 to $3.5 \mathrm{~h}$, an initial delay in the growth of strain 37 in mixed culture was observed. The viable cell count of strain 37 in mixed culture increased markedly between 3.5 and $7 \mathrm{~h}$, and at the end of the culture period the counts for this strain in pure culture $(9.09 \pm 0.09$ $\log \mathrm{cfu} / \mathrm{mL})$ and mixed culture $(9.02 \pm 0.12 \log \mathrm{cfu} /$ $\mathrm{mL})$ were comparable $(P=1.00)$. The growth of strain 54 in pure and mixed cultures was similar, and the viable counts for this strain in pure culture $(8.61 \pm 0.09$ $\log \mathrm{cfu} / \mathrm{mL})$ and mixed culture $(8.84 \pm 0.09 \log \mathrm{cfu} /$ $\mathrm{mL})$ were comparable $(P=0.91)$ at $24 \mathrm{~h}$. A significant decrease in the $\mathrm{pH}$ value of the milk medium in mixed culture compared with each pure culture was observed at 7 and $24 \mathrm{~h}$ (Figure 1b).

When inoculating the 2 cultures 3 times in milk, we found that strains 37 and 54 grew in milk at a constant rate (data not shown).

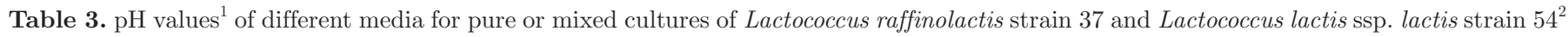

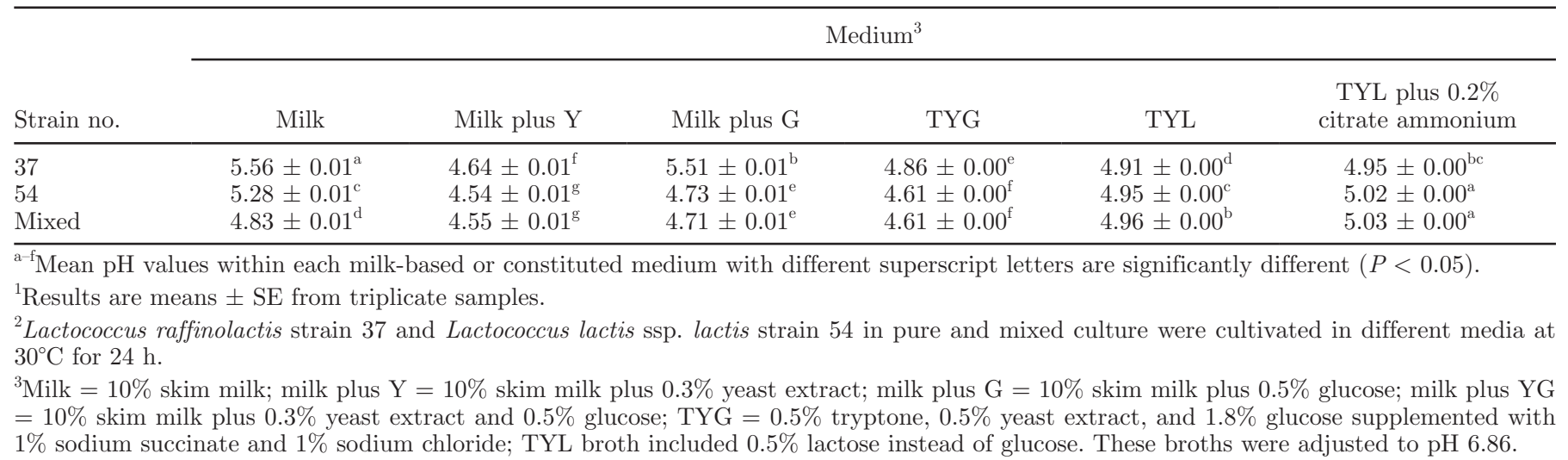


Table 4. Effect of cell-free extract from milk fermented by Lactococcus lactis ssp. lactis strain 54 on the $\mathrm{pH}$ values ${ }^{1}$ of milk fermented by Lactococcus raffinolactis strain $37^{2}$

\begin{tabular}{lc}
\hline Sample & $\mathrm{pH}$ \\
\hline Distilled water & $5.68 \pm 0.01^{\mathrm{b}}$ \\
Whey from control & $5.78 \pm 0.01^{\mathrm{a}}$ \\
Whey from strain 54 & $5.34 \pm 0.01^{\mathrm{c}}$ \\
\hline
\end{tabular}

${ }^{\mathrm{a}-\mathrm{c}}$ Mean $\mathrm{pH}$ values with different superscript letters were significantly different $(P<0.05)$.

${ }^{1}$ Results are means \pm SE from triplicate samples.

${ }^{2}$ Lactococcus raffinolactis strain 37 was cultivated with the cell-free extract in $10 \%$ skim milk or distilled water at $30^{\circ} \mathrm{C}$ for $24 \mathrm{~h}$.

\section{Taste Intensities of Pure and Mixed Cultures in Fermented Milk}

The relative intensities of the taste of milk fermented by pure and mixed cultures compared with sensory buffer solution are shown in Table 5. Significant differences in initial tastes of saltiness, acidity, umami, and anionic bitterness and aftertastes of anionic bitterness and astringency were detected between fermented milk samples of strains 37 and 54. In mixed cultures, fermented milk had significantly higher intensities of acidity and anionic bitterness, and aftertastes of bitterness and astringency and significantly lower intensities of saltiness and umami than in either culture alone. Addition of fermented milk of strain 37 to that of strain 54 (1:1) produced significantly different taste intensities (i.e., saltiness, acidity, umami, anionic bitterness, and aftertastes of bitterness, umami, and astringency) compared with the mixed cultivation sample.

\section{DISCUSSION}

Raw milk is a source of new strains of lactic acid bacteria (Badis et al., 2004; Nomura et al., 2006). The indigenous bacterial community in milk can be influenced by cow feeding conditions, such as feeding systems and season (Lopez-Benavides et al., 2007; Hagi et al., 2010). Further, to apply lactic acid bacterial strains as dairy starters, we selectively identified strains that grow well in milk with yeast extract and glucose. Thus, although our results for lactic acid bacterial species and populations isolated from raw milk may not be directly extrapolated to other experimental conditions (e.g., different countries, animals, or feeding systems), bacterial species isolated from raw cow milk in this study, except Weissella spp., were found in other studies (Giannino et al., 2009; Hagi et al., 2010). Although there are no reports of Weissella isolated from raw milk, this genus has been isolated from traditional fermented milk products (Sengun et al., 2009).

Associative growth between L. lactis ssp. lactis strain 54 and L. raffinolactis strain 37 was observed in milk
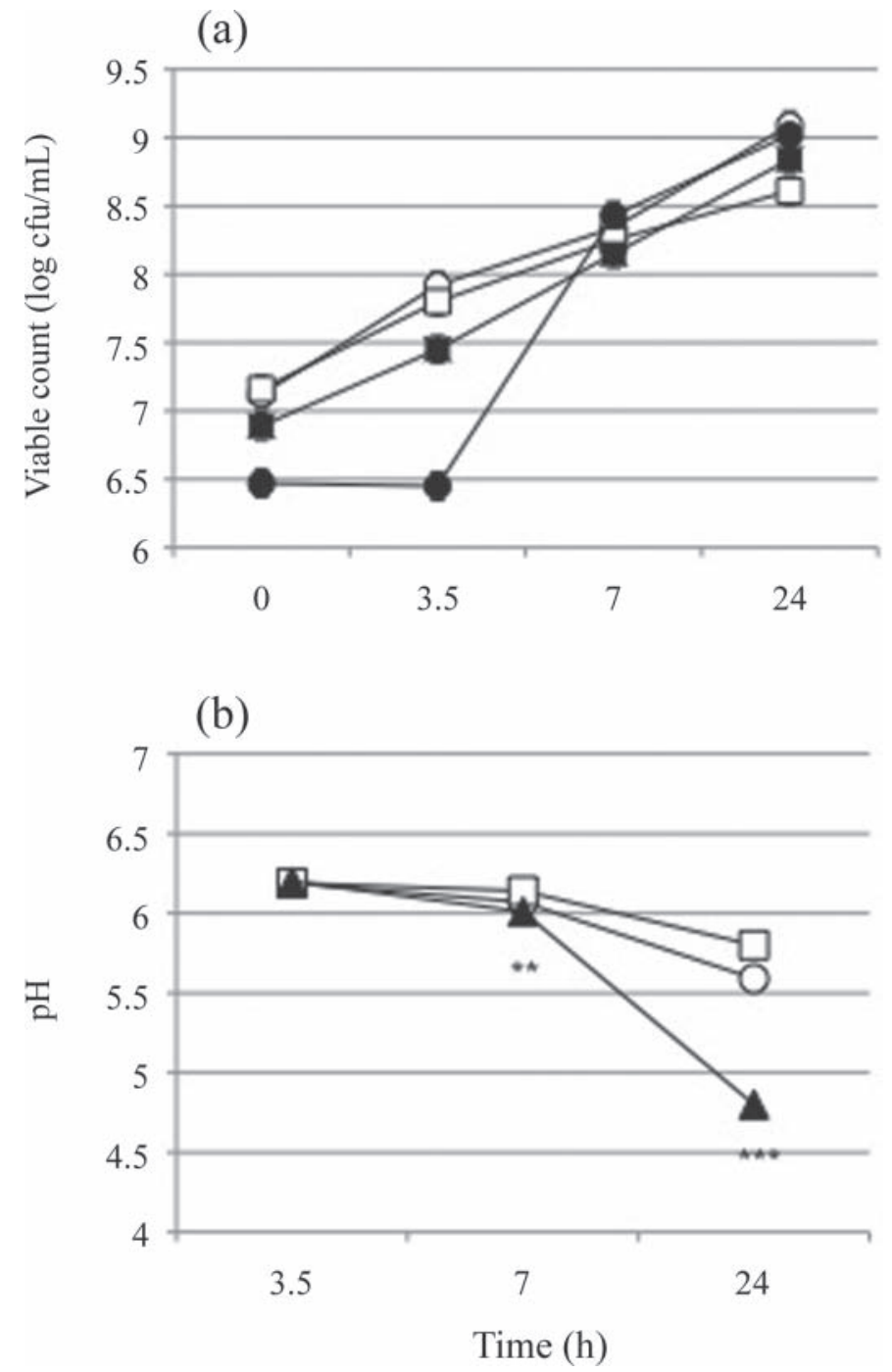

Figure 1. Viable cell count (a) and $\mathrm{pH}$ value (b) in pure and mixed cultures of Lactococcus raffinolactis strain 37 and Lactococcus lactis ssp. lactis strain 54 in $10 \%$ skim milk. (a) Viable cell counts of strain 37 in pure culture $(\bigcirc)$ and mixed culture $(\bullet)$ and strain 54 in pure culture $(\square)$ and mixed culture $(\square)$; (b) pH values of strain $37(\bigcirc)$ and strain No. $54(\square)$ in pure culture and mixed culture $(\boldsymbol{\Lambda})$. Data are the means of 2 or 3 replicate samples. The $\mathrm{pH}$ values of mixed culture versus that of each pure culture: ${ }^{* *} P<0.01$; ${ }^{* * *} P<0.001$.

but not in milk with yeast extract or glucose and in constituted medium. This was because proteinaceous compounds, amino acids, or other available carbon sources or minerals derived from these media stimulate bacterial growth in pure culture, suggesting that these 2 strains need minerals and amino acids for growth. Lactococcus lactis strains have limited capacity to synthesize amino acids (Chopin, 1993) and depend on nitrogen sources, such as casein in milk, for growth. These 2 strains behave like nonproteolytic strains, although strain 54 coagulated milk when glucose was 
added. This strain is protease-positive, but its activity may be low.

Cultures that grow symbiotically supply each other with needed nutrients and thus can grow well in deficient media, as observed for yogurt starters. The acid production of strain 37 was stimulated by metabolites from milk fermented by strain 54 . In terms of the bacterial growth curve, although we observed an initial delay in the growth of strain 37 in mixed culture because of its lower inoculum, its growth increased markedly thereafter, which may correspond to the exponential growth period in strain 54. In contrast, the growth curve of strain 54 was unaffected by mixing with strain 37. These findings indicate that strain 37 may not provide milk metabolites for strain 54 in mixed culture. In other words, the stimulatory action was one-sided; that is, this interaction between strains 37 and 54 represents commensalism (Meers, 1973). The stimulatory materials in milk fermented by strain 54 have not yet been identified. In addition, by inoculating 3 times, we found that strains 37 and 54 grew in milk at a constant rate, indicating that each strain may not be eliminated from mixed culture because of its sensitivity to bacteriocins produced by the other strain, if the strains produce them.

Although few reports exist on the interactions among L. lactis strains (Kothari et al., 1971; Juillard et al., 1996; Flambard et al., 1997), there are no reports on commensalism between $L$. lactis and L. raffinolactis. Significant acid production in mixed culture between L. raffinolactis strain 37 and L. lactis ssp. lactis strains 22,36 , or 95 was observed (data not shown), similar to that occurring in mixed cultures of strains 37 and 54 . Further investigation of the stimulatory materials from strains 22,36 , or 95 on strain 37 are needed. When a $L$. lactis ssp. lactis strain has beneficial industrial traits, such as production of a desirable flavor, but shows poor growth in milk, the time required for acid production might be shortened by mixing strain 37 with slowgrowing strains of L. lactis ssp. lactis in milk, which may be useful for developing a new dairy starter.

Lactococcus raffinolactis strains are not currently used by the dairy industry, mainly because of their lack of caseinolytic activity (Holler and Steele, 1995), although some strains of $L$. raffinolactis have been detected in traditionally fermented milk products such as Zabady in Egypt (El-Baradei et al., 2008) and Kajmak in the Balkan Peninsula (Jokovic et al., 2008). Is there merit in utilizing $L$. raffinolactis as an industrial dairy starter? We investigated the symbiosis between L. raffinolactis strain 37 and dairy starter L. lactis ssp. cremoris strain H61 (Kimoto-Nira et al., 2007) in this study. Although mixed cultivation of strains 37 and H61 did not promote acid production compared with 
that of each pure culture, strain 37 was not eliminated by mixed cultivation with strain H61 (data not shown). Strain 37 fermented lactose and citrate to lactate, formate, acetate, ethanol, and acetoin (data not shown). Flavor compounds such as acetoin have been reported in dairy products (Callon et al., 2005; Chammas et al., 2006). For example, diacetyl and its reduced form, acetoin, are of interest for their organoleptic properties and are responsible for notes of a fermented buttery flavor. Because L. lactis ssp. cremoris strains, such as strain $\mathrm{H} 61$, are not able to utilize citrate, strain 37 might add a different flavor to fermented milk products made by dairy starters of L. lactis ssp. cremoris.

On the other hand, L. raffinolactis strains are able to ferment $\alpha$-galactosides, such as melibiose and raffinose, that are not utilized by L. lactis strains (Boucher et al., 2003). These sugars are dominant in plant-derived foods, such as soymilk, and are known to cause flatulence. Recent trials of their removal by fermentation with lactic acid bacteria have been reported (LeBlanc et al., 2004; Machielsen et al., 2011). To develop dairy products with new organoleptic properties, it would be useful to mix milk with plant-derived materials (i.e., soymilk, fruits, and vegetables) and ferment it with lactic acid bacteria, such as a mixture of $L$. raffinolactis strain 37 and L. lactis ssp. lactis strain 54 or other dairy starters.

Several natural isolated strains are presently used as starter bacteria. For example, L. lactis ssp. lactis 527 (MAFF 400103, Ministry of Agriculture, Forestry and Fisheries, Tsukuba, Japan) was isolated from raw cow milk and has been used as starter bacteria for more than 50 yr (Kimoto et al., 1999). Trials have also been conducted to apply lactic acid bacteria isolated from the natural environment, such as raw milk (Fortina et al., 2007; Bravo et al., 2009) and plant material (Nomura et al., 2006), to making dairy products. However, if natural isolated strains are to be developed as new starter organisms, their safety must be assessed, even if they are generally recognized as safe, because the incidence of virulence factors such as antibiotic resistance and production of undesirable substances seem to be strain-specific properties (Fortina et al., 2007).

\section{CONCLUSIONS}

Mixed culture of L. lactis ssp. lactis strain 54 and L. raffinolactis strain 37 isolated from raw cow milk may be useful for developing new dairy products. In addition to assessing their safety, further evaluation of traits such as their resistance to bacteriophages and organoleptic evaluation by panelist will be required.

\section{ACKNOWLEDGMENTS}

We thank C. Koitabashi, X. Y. Yu, and M. Nishimura (NARO Institute of Livestock and Grassland Science, Ibaraki, Japan) for their technical assistance, and K. Chikuni (NARO Institute of Livestock and Grassland Science) for analysis of the taste-sensing system.

\section{REFERENCES}

Anjiki, N., J. Hosoe, H. Fuchino, F. Kikushi, A. Sekita, H. Ikezaki, M. Mikage, N. Kawahara, and Y. Goda. 2011. Evaluation of the taste of crude drug and Kampo formula by a taste-sensing system (4): Taste of Processed Aconite Root. J. Nat. Med. 65:293-300.

Badis, A., D. Guetarni, B. Moussa Boudjemaa, D. E. Henni, and M. Kihal. 2004. Identification and technological properties of lactic acid bacteria isolated from raw goat milk of four Algerian races. Food Microbiol. 21:579-588.

Boquien, C.-Y., G. Corrieu, and M. J. Desmazeaud. 1988. Effect of fermentation conditions on growth of Streptococcus cremoris AM2 and Leuconostoc lactis CNRZ 1091 in pure and mixed cultures. Appl. Environ. Microbiol. 54:2527-2531.

Boucher, I., C. Vadeboncoeur, and S. Moineau. 2003. Characterization of genes involved in the metabolism of $\alpha$-galactosides by Lactococcus raffinolactis. Appl. Environ. Microbiol. 69:4049-4056.

Bramley, A. J., C. H. McKinnon, R. T. Staker, and D. L. Simpkin. 1984. The effect of udder infection on the bacterial flora of the bulk milk of ten dairy herds. J. Appl. Bacteriol. 57:317-323.

Bravo, D., E. Rodriguez, and M. Medina. 2009. Nisin and lacticin 481 coproduction by Lactococcus lactis strains isolated from raw ewes' milk. J. Dairy Sci. 92:4805-4811.

Callon, C., J. L. Berdague, E. Dufour, and M. C. Montel. 2005. The effect of raw milk microbial flora on the sensory characteristics of Salers-type cheeses. J. Dairy Sci. 88:3840-3850.

Chammas, G. I., R. Saliba, G. Corrieu, and C. Beal. 2006. Characterization of lactic acid bacteria from fermented milk "Laban". Int. J. Food Microbiol. 110:52-61.

Chee, C. P., J. J. Gallaher, D. Djordijevic, H. Faraji, D. J. McClements, E. A. Decker, R. Hollender, D. G. Peterson, R. F. Roberts, and J. N. Coupland. 2005. Chemical and sensory analysis of strawberry flavoured yogurt supplemented with an algae oil emulsion. J. Dairy Res. 72:311-316.

Chikuni, K., M. Oe, K. Sasaki, M. Shibata, I. Nakajima, K. Ojima, and S. Muroya. 2010. Effects of muscle type on beef taste-traits assessed by an electric sensing system. Anim. Sci. J. 81:600-605.

Chopin, A. 1993. Organization and regulation of genes for amino acids biosynthesis in lactic acid bacteria. FEMS Microbiol. Rev. 12:21-37.

Cogan, T. M. 1978. Determination of growth rates of lactic starter cultures. Int. J. Food Sci. Technol. 2:105-115.

Crittenden, R. G., N. R. Martinez, and M. J. Playne. 2003. Synthesis and utilization of folate by yogurt starter cultures and probiotic bacteria. Int. J. Food Microbiol. 80:217-222.

Derzelle, S., A. Bolotin, Y. Miston, and F. Rul. 2005. Proteome analysis of Streptococcus thermophilus grown in milk reveals pyruvate formate-lyase as the major upregulated protein. Appl. Environ. Microbiol. 71:8597-8605.

Driessen, F. M., F. Kingma, and J. Stadhouders. 1982. Evidence that Lactobacillus bulgaricus in yogurt is stimulated by carbon dioxide produced by Streptococcus thermophilus. Neth. Milk Dairy J. $36: 135-144$

El-Baradei, G., A. Delacroix-Buchet, and J. C. Ogier. 2008. Bacteria biodiversity of traditional Zabady fermented milk. Int. J. Food Microbiol. 121:295-301.

Flambard, B., J. Richard, and V. Juillard. 1997. Interaction between proteolytic strains of Lactococcus lactis influenced by different 
types of proteinase during growth in milk. Appl. Environ. Microbiol. 63:2131-2135.

Fortina, M. G., G. Ricci, R. Foschino, C. Picozzi, P. Dolci, G. Zeppa, L. Cocolin, and P. L. Manachini. 2007. Phenotypic typing, technological properties and safety aspects of Lactococcus garvieae strains from dairy environments. J. Appl. Microbiol. 103:445-453.

Frengova, G. I., E. D. Simova, D. M. Beshkova, and Z. I. Simov. 2000. Production and monomer composition of exopolysaccharides by yogurt starter cultures. Can. J. Microbiol. 46:1123-1127.

Galle, S., C. Schwab, E. Arendt, and M. Ganzle. 2010. Exopolysaccharide-forming Weissella strains as starter cultures for sorghum and wheat sourdoughs. J. Agric. Food Chem. 58:5834-5841.

Giannino, M. L., M. Marzotto, F. Dellaglio, and M. Feligini. 2009 Study of microbial diversity in raw milk and fresh curd used for Fontina cheese production by culture-independent methods. Int. J. Food Microbiol. 130:188-195.

Hagi, T., M. Kobayashi, and M. Nomura. 2010. Molecular-based analysis of changes in indigenous milk microflora during the grazing period. Biosci. Biotechnol. Biochem. 74:484-487.

Herve-Jimenez, L., I. Guillouard, E. Guedon, S. Boudebbouze, P. Hols, V. Monnet, E. Maguin, and F. Rul. 2009. Post-genomic analysis of Streptococcus thermophilus co-cultivated in milk with Lactobacillus delbreukii ssp. bulgaricus: involvement of nitrogen, purine and iron metabolism. Appl. Environ. Microbiol. 75:2062-2073.

Holler, B. J., and J. L. Steele. 1995. Characterization of lactococci other than Lactococcus lactis for possible use as starter cultures. Int. Dairy J. 5:275-289.

Hugenholtz, J., R. Splint, W. N. Konings, and H. Veldkamp. 1987. Selection of protease-positive and protease-negative variants of Streptococcus cremoris. Appl. Environ. Microbiol. 53:309-314

Isleten, M., and Y. Karagul-Yuceer. 2006. Effects of dried dairy ingredients on physical and sensory properties of nonfat yogurt. J. Dairy Sci. 89:2865-2872.

Jokovic, N., M. Nikolic, J. Begovic, B. Jovcic, D. Savic, and L. Topisirovic. 2008. A survey of the lactic acid bacteria isolated from Serbian artisanal dairy product kajmak. Int. J. Food Microbiol. 127:305-311.

Juillard, V., S. Furlan, C. Foucand, and J. Richard. 1996. Mixed cultures of proteinase-positive and proteinase-negative strains of $\mathrm{Lac}$ tococcus lactis in milk. J. Dairy Sci. 79:964-970.

Kimoto, H., J. Kurisaki, N. M. Tsuji, S. Ohmomo, and T. Okamoto. 1999. Lactococci as probiotic strains: Adhesion to human enterocyte-like Caco-2 cells and tolerance to low $\mathrm{pH}$ and bile. Lett. Appl. Microbiol. 29:313-316.

Kimoto-Nira, H., C. Suzuki, M. Kobayashi, K. Sasaki, J. Kurisaki, and K. Mizumachi. 2007. Anti-aging effect of a lactococcal strain: Analysis using senescence-accelerated mice. Br. J. Nutr. 98:11781186.

Kothari, S. L., V. K. N. Nambudrupad, and H. Laxminarayana. 1971. Studies on the associative growth of streptococci. Milchwissenschaft 26:415-418.

LeBlanc, J. G., A. Silvestroni, C. Connes, V. Julliard, G. S. de Giori, J. C. Piard, and F. Sesma. 2004. Reduction of non-digestible oligosaccharides in soymilk: Application of engineered lactic acid bacteria that produce alpha-galactosidase. Genet. Mol. Res. 3:432-440.

Lopez-Benavides, M. G., J. H. Williamson, G. D. Pullinger, and S. J. Lacy-Hulbert. 2007. Field observations on the Streptococcus uberis populations in a pasture-based dairy farm. J. Dairy Sci. 90:5558-5566.

Machielsen, R., R. J. Siezen, S. A. F. T. van Hijum, and J. E. T. van Hylckama Vlieg. 2011. Molecular description and industrial potential of Tn6098 conjugative transfer conferring alpha-galactoside metabolism in Lactoocccus lactis. Appl. Environ. Microbiol. $77: 555-563$.

Margulis, L. 1996. From kefir to death. Pages 69-78 in How Things Are. J. Brockman, and K. Maston, ed. William Morrow and Co., New York, NY.
Meers, J. L. 1973. Growth of bacteria in mixed cultures. Crit. Rev. Microbiol. 2:139-184.

Naser, S. M., P. Dawyndt, B. Hoste, D. Gevers, K. Vandemeulebroecke, I. Cleenwerck, M. Vancanneyt, and J. Swings. 2007. Identification of lactobacilli by pheS and rpoA gene sequence analyses. Int. J. Syst. Evol. Microbiol. 57:2777-2789.

Naser, S. M., F. L. Thompson, B. Hoste, D. Gevers, P. Dawyndt, M. Vancanneyt, and J. Swings. 2005. Application of multilocus sequence analysis (MLSA) for rapid identification of Enterococcus species based on rpoA and pheS genes. Microbiology 151:21412150.

Nomura, M., M. Kobayashi, T. Narita, H. Kimoto-Nira, and T. Okamoto. 2006. Phenotypic and molecular characterization of Lactococcus lactis from milk and plants. J. Appl. Microbiol. 101:396405.

Nomura, M., M. Kobayashi, and T. Okamoto. 2002. Rapid PCR-based method which can determine both phenotype and genotype of Lactococcus lactis subspecies. Appl. Environ. Microbiol. 68:22092213.

Ogier, J. C., E. Casalta, C. Farrokh, and A. Saihi. 2008. Safety assessment of dairy microorganisms: the Leuconostoc genus. Int. J. Food Microbiol. 126:286-290.

Pu, Z. Y., M. Dobos, G. K. Limsowtin, and I. B. Powell. 2002. Integrated polymerase chain reaction-based procedures for the detection and identification of species and subspecies of the gram-positive bacterial genus Lactococcus. J. Appl. Microbiol. 93:353-361.

Rogosa, M., J. A. Mitchell, and R. F. Wiseman. 1951. A selective medium for the isolation and enumeration of oral and fecal lactobacilli. J. Bacteriol. 62:132-133

Salminen, S., A. von Wright, L. Morelli, P. Marteau, D. Brassart, W. M. de Vos, R. Fonden, M. Saxelin, K. Collins, G. Mogensen, S. E. Birkeland, and T. Mattila-Sandholm. 1998. Demonstration of safety of probiotics-a review. Int. J. Food Microbiol. 44:93-106.

Sasaki, K., F. Tani, K. Sato, H. Ikezaki, A. Taniguchi, T. Emori, F. Iwaki, K. Chikuni, and M. Mitsumoto. 2005. Analysis of pork extracts by taste sensing system and the relationship between Umami substances and sensor output. Sensor Mater. 17:397-404.

Sengun, I. Y., D. S. Nielsen, M. Karapinar, and M. Jakobsen. 2009. Identification of lactic acid bacteria isolated from Tarhana, a traditional Turkish fermented food. Int. J. Food Microbiol. 135:105111

Sieuwerts, S., F. A. M. de Bok, J. Hugenholtz, and J. E. T. van Hylckama Vlieg. 2008. Unraveling microbial interactions in food fermentations: From classical to genomic approaches. Appl. Environ. Microbiol. 74:4997-5007.

Simova, E., D. Beshkova, A. Angelov, Ts. Hristozova, G. Frengova, and Z. Spasov. 2002. Lactic acid bacteria and yeasts in kefir grains and kefir made from them. J. Ind. Microbiol. Biotechnol. 28:1-6.

Simova, E., Z. Simov, D. Beshkova, G. Frengova, Z. Dimitrov, and Z. Spasov. 2006. Amino acid profiles of lactic acid bacteria, isolated from kefir grains and kefir starter made from them. Int. J. Food Microbiol. 107:112-123.

Suzuki, M. T., and S. J. Giovannoni. 1996. Bias caused by template annealing in the amplification of mixtures of $16 \mathrm{~S}$ rRNA genes by PCR. Appl. Environ. Microbiol. 62:625-630.

Thompson, J. L., K. Lopetcharat, and M. A. Drake. 2007. Preferences for commercial strawberry drinkable yogurts among African America, Caucasian, and Hispanic consumers in the United States. J. Dairy Sci. 90:4974-4987.

Toko, K. 1996. Taste sensor with global selectivity. Mater. Sci. Eng. C $4: 69-82$.

Toko, K. 1998. Electric tongue. Biosens. Bioelectron. 13:701-709. 